\title{
Miguel Reale e a Renovação dos Estudos Jurídicos no Brasil *.
}

\author{
Teófilo Cavalcanti Filho \\ (Docente livre de Introdução à Ciência do \\ Direito, da Faculdade de Direito da Univer- \\ sidade de São Paulo e membro do IBF de \\ São Paulo).
}

Vinte e cinco anos formam periodo suficientemente prolongado ou exiguo, dependendo da perspectiva por que o contemplemos. KaNT, após uma vida excepcionalmente trabalhosa, lamentava que fôsse demasiado curta para a realização da tarefa que se propusera. Os anos se medem, assim, pelo projeto humano a que correspondem. Serão suficientes ou insuficientes, serão muitos ou serão poucos, de acôrdo com o plano pessoal de cada um, que fornece a perspectiva para a sua própria avaliação. Se se pudesse encarar o tempo, como algo inteiramente independente da vida pessoal, da conjuntura humana, certamente se deveria considerar um quarto de século como algo dilatado, como uma marca avançada, que corresponde a uma geração inteira. Mas com isso, insensível e mesmo involuntàriamente, já se estaria colocando um contexto humano, para comparação, a fim de dar significado à temporalidade, que jamais seria assim pura, mas sim algo que adquire expressão quando posta em cotejo com algo humano. Fala-se, com freqüência, em aceleração do tempo, em uma maior ou menor vertiginosidade no seu transcurso, mas os que a isso se referem esquecem-se de que, ao invés do tempo, do do direito.

Parte de um livro em preparo sôbre a teoria tridimensional 
transcorrer puro e simples, estão aludindo a acontecimentos humanos, a transformações humanas, a fatos que envolvem o homem, que no fundo é a marca do tempo, o senhor do acontecer, do transcorrer numa sucessão infindável. Bergson notou que o homem espacializa o tempo, a fim de poder agir com maior eficiência e facilidade. Percebeu, todavia, apenas um aspecto, sem dúvida de grande importância, mas nada mais do que um aspecto, do fenômeno que traduz um viver total, que implica uma manifestação global do existir humano em sua radical amplitude. Aí está porque, quando se pretende analisar a obra de um homem, é antes de tudo necessário volver-se para ela própria, mas visualizando-a no seu desenvolver temporal, porque os dois aspectos se implicam, se englobam, se tornam inseparáveis. Há uma dimensão temporal, em tôda obra humana, notadamente nas obras espirituais. Na essência mesma da espiritualidade, seja qual fôr a sua manifestação, existe uma nota de temporalidade, de fuga ao quantitativo, de repúdio ao espacial. Por isso, a significação de qualquer obra do gênero se mede pelo conteúdo significativo que apresenta e não pela maior ou menor duração que exigiu para ser realizada, ou pela maior ou menor soma de energia que foi necessária para moldá-la. Não obstante isso, o tempo interfere, de maneira considerável, na apreciação da importância maior ou menor que o projeto humano encerre. Mas a temporalidade, no caso, diz mais respeito à significação em si mesma da obra desenvolvida do que ao tempo que foi necessário gastar para realizá-la. A duração, em sentido de permanência atuante, de presença em sentido real, é aspecto dos mais sugestivos para demonstrar a densidade humana da obra humana.

Assim, o marco temporal de um trabalho deve servir tão sòmente de indicação, de advertência para a verificação daquelas condições, que traduzem e refletem a significação do trabalho espiritual. É nesse sentido, e sòmente nesse sentido, que nos deve preocupar o transcurso do vigésimo quinto aniversário de atividade docente do prof. Reale, que 
está sendo orgulhosamente assinalado, e com tôda a razão, pela Faculdade de Direito da Universidade de São Paulo. $O$ que importa, todavia, é fazer um levantamento da atividade desenvolvida pelo eminente professor nesses vinte e cinco anos, fixando a sua eventual significação.

\section{II.}

Temos para nós que nada melhor expressaria a importância real, significativa portanto, da atividade docente do ilustre Mestre, do que uma verificação exata do que ela trouxe para a mentalidade jurídica nossa, para a nossa consciência jurídica. Constitui lugar comum afirmar-se que o Mestre molda espíritos. A nosso ver, o verdadeiro Mestre não se limita a reproduzir o que a experiência das gerações anteriores lhe propiciou, mas procura impulsionar as novas gerações, aparelhando-as para a realização de uma obra que o futuro exige. A moldagem de espírito, que um refrão conhecido acentua, sòmente pode ser entendida com autênticidade dessa forma. Se se encarassem as coisas de outro modo, dificilmente a ciência progrediria. A sabedoria seria estática. A atividade intelectual não passaria de uma monótona e esteril repetição de posições já estabelecidas. 0 progresso, em sentido real, pràticamente inexistiria. 0 Mestre, entretanto, é e deve ser um típico propulsor de progresso, de rasgador de horizontes, no sentido efetivo de descobridor e pregoeiro de novas perspectivas. O seu papel fundamental está nisso, em revelar novas perspectivas e indicar os meios que permitam descobri-las e ultrapassá-las em perspectivas novas, capazes de propiciar novas conquistas, novas descobertas, que representem acréscimos efetivos à cultura, entendida esta na totalidade de sua compreensão. Dizendo isso, evidentemente, estaremos também levando em conta 0 aspecto moral, que não se desvincula do intelectual, e estaremos apenas colocando de maneira mais particularizada e explícita o conceito de homem, no desdobramento infinito de suas possibilidades. 


\section{III.}

O que se impõe portanto é fazer a indagação fundamental, concernente a saber o que a atividade docente de REALE representou em avanço, em desdobramento de novas perspectivas, em estímulo, em progresso, naquele sentido que acabamos de indicar. Terá trazido algo de novo, algo de anteriormente inexistente, algo que importasse em mudança na maneira até então dominante de encarar o direito, de compreender a realidade jurídica?

Pensamos encontrar-nos em situação privilegiada para dar, a tal respeito, o nosso testemunho. E com êle, para proceder a um levantamento cuidadoso da repercussão do trabalho desenvolvido pelo incansável autor da Teoria do Direito e do Estado.

Integramos a turma que, em 1944, seria das primeiras a receber as lições orais do novo catedrático de Filosofia do Direito. Assumira êle a regência da Cadeira a 15 de maio de 1941, mas pouco tempo depois iria interromper a atividade docente em virtude de nomeação para membro do Departamento Administrativo do Estado, cujas funções passaria a exercer, a partir de 14 de janeiro de 1942.

Ascendera à Cátedra, após concurso que alcançara a maior repercussão, com uma tese hoje rara, Fundamentos do Direito, na qual ventilava idéias geralmente desconhecidas em nossos meios jurídicos e mesmo filosóficos.

As provas do concurso, notadamente as de argüição, a que tivemos a ventura de assistir, e de cujas passagens fundamentais conservamos ainda hoje na memória trechos bastante sugestivos, deixaram a impressão, no espírito do adolescente de então, despreparado, òbviamente, para avaliar com exatidão as objeções e as respostas, de uma colidência frontal de mentalidades e de idéias. De um lado, alguns mestres, de provecta competência e de grande conhecimento, mas aferrados a posições tradicionais; e de outro, o candidato, revelando grande poder de argumentação e 
serenidade, procurando ventilar idéias novas, colhidas em correntes de pensamento que não haviam encontrado ainda boa acolhida sob as Arcadas.

Temos ainda bem presente a radical divergência que se estabeleceu entre um argüente, por sinal professor de outra Faculdade, ${ }^{1}$ e o candidato. A memória reteve a passagem, mais por causa do aspecto físico do examinador, que ao falar lançava uma longa cabeleira sôbre os olhos, do que pròpriamente pelo dialogo, que só posteriormente haveria de se nos tornar sensivel, demonstrando um choque de posições que de certo modo traduzia um conflito mais amplo, existente entre os vários juristas brasileiros. 0 argüente não podia, e o confessava sem rebuços, conceber a separação entre o mundo do ser e o do dever ser, e menos ainda a possibilidade de uma conciliação entre ambos, numa esfera nova, como a que apregoava o argüido, em seu ensaio, onde as idéias culturalistas tinham ampla repercussão. O ponto que suscitou divergência ainda maior foi o capítulo conclusivo da tese, intitulado Fato, Valor e Norma ${ }^{2}$, onde já se enunciava, embora de forma ainda imprecisa, talvez mesmo vacilante, o tridimensionalismo, que haveria de celebrizar o seu autor e torná-lo um dos nossos mais influentes juristas. A rigor, nesse diálogo, transparecia o choque a que acima aludímos, de maneira mais flagrante, entre as posições até então predominantes, e a posição nova, que indicava novos rumos para o pensamento jurídico universal e que já empolgava as novas gerações de juristas europeus.

Os demais integrantes da banca examinadora, exceção aberta para dois únicos, os profs. Hahnemann Guimarães e Mario MaZagãa, se encontravam em situação idêntica, isto é, de divergência radical com o candidato. A divergência, que é normal no campo das idéias, e até mesmo útil para o intercâmbio espiritual, no caso assumia caracteristicas especiais, isto é, de inconciliabilidade flagrante, dadas as po-

1. Trata-se do Prof. Edgard SANChes, da Bahia.

2. Miguel Reale, Fundamentos do Direito, Capítulo VIII, São Paulo, 1940. 
sições prèviamente estabelecidas. Forçoso é reconhecer que os profs. Mario Mazagão e Hahnemann Guimarães mantinham divergências, mas nem por isso se mostravam insensiveis aos novos princípios. Mesmo assim, ao que tudo indica, só o segundo manifestou simpatia, embora de modo restrito, para a mensagem que o livro oferecia à mentalidade juridica brasileira. O primeiro, dada a familiaridade que mantinha com a filosofia hegeliana, tinha condições mais do que suficientes para uma apreciação simpática da obra, mas não condescendia com as conclusões que apregoava.

O que importa porém ressaltar, nesse levantamento que estamos realizando, é essa circunstância da maior importância, que se revelara no concurso de 1940 . No debate que se travou, entravam em choque duas posições, fixando-se de um lado a que procurava manter-se e de outro a que procurava impor-se, em substituição à primeira.

Esse ponto, aliás, foi já na época salientado por um arguto analista de nossas idéias, Tristão de Ataide, o qual, em nota critica que então publicou, reconheceu que Fundamentos do Direito trazia uma contribuição inestimável para a renovação dos estudos jurídicos no país.

Examinado êsse livro, à altura em que hoje nos encontramos, nenhuma dúvida há de que vale sobretudo pelo que prometia de novo. A uma leitura atual, entretanto revela, a cada página, a cada passo mesmo, uma notável inquietação, uma insatisfação irrequieta por tudo o que se oferecia, valendo também pelo que negava, pelo que procurava destruir. Com argúcia admirável, punha à mostra as falhas das doutrinas então em voga, as incertezas e incongruências, num esfôrço vigoroso para abrir caminho e identificar o caminho certo, que conduziria ao mistério da realidade jurídica. $\mathrm{E}$ de fato, numa verdadeira clarinada, ouve-se, no final, a sinfonia tridimensionalista, que é antes enunciada do que delineada, e mesmo no que diz, fica apenas num esbôço, que será completado, alargado, modificado, através de vinte e cinco anos de trabalho ininterrupto. 
Certo, os alicerces aí já se encontram, mas êles próprios seriam depois robustecidos com seiva nova, oriundos especialmente do hegelianismo, do historicismo, e da fenomenologia.

IV.

Permita-se-nos uma pausa, para reexame, embora ligeiro. Fundamentos do Direito ocupa uma posição singular, na obra de REale, posição que sòmente pode ser exatamente compreendida através de um exame retrospectivo da sua obra anterior. Através de uma contemplação dessa natureza, Teoria do Direito $e$ do Estado, que apareceu quase concomitantemente ${ }^{3}$, é que é uma obra que marca um ciclo evolutivo no pensamento do autor. É o trabalho conclusivo de estudos e ensaios àrduamente empreendidos, a partir de $O$ Estado Moderno, alcançando momento culminante em Atualidades de um Mundo Antigo. Tôda a elaboração doutrinária, que corre através das obras referidas, bem como de numerosos ensaios, esparsos por revistas e jornais, encontrava a sua formulação definitiva na Teoria do Direito e do Estado, que principalmente depois dos retoques recebidos, em 1959, continua a ser um dos trabalhos mais bem construídos do autor.

Seria difícil, ou mesmo impossivel, conceber-se Fundamentos do Direito sem essa elaboração anterior. Sobretudo, sem a meditação dos temas relativos à Teoria do Direito e à Teoria do Estado, à História, à Cultura, ao Homem, à Concepção do Mundo, que se refletem em tôdas as obras enunciadas. Seria impossível ao autor ter a visão da realidade juridica, que enuncia na sua tese de 1940 , sem o estudo e a reflexão pessoal da massa enorme de material doutrinário acumulado nos livros anteriores. Mas é indiscutivel que Fundamentos reponta, com originalidade, não

3. Miguet Reale, Teoria do Direito e do Estado, edição de 1940, Editora Martins. A 2. ${ }^{a}$ edição, da mesma editora, de 1959, se diferencia substancialmente da primeira. 
revelando pròpriamente travamento algum, no que diz respeito à concepção e planejamento, com os trabalhos antecedentes. De certa forma, porém, apresenta um reexame do material acumulado, para servir de base a uma idéia antes não surpreendida. É todavia indiscutivel que flui, através de todos os indicados trabalhos, a mesma concepção fundamental, numa admirável coerência especulativa. O que há é que Fundamentos de repente, surge a indicar um rumo novo, que claramente não fôra ainda esboçado, embora a uma análise retrospectiva se sinta que guarda afinidade lógica indiscutivel com todo o material anterior. Poder-se-ia mesmo afirmar que, desde o primeiro livro, numa ascenção bastante significativa, as idéias vão-se somando, num crescendo notável, e estendendo-se a novos campos. Mas a mesma concepção básica se mantém e vai penetrando novos setôres, colorindo-os expressivamente. Haja vista esta observação, que resume, através de uma posição metódica precisa, a concepção central realeana, que já se vislumbra no pórtico de Atualidades do Mundo Antigo - "Não é possivel a ciència do homem sòmente segundo as leis de causa eficiente, a não ser que se aceite, de antemão, o princípio de que o homem é um pedaço de natureza, um pedaço da sociedade, subordinado inexoràvelmente às leis desta. Então a história passaria a ser uma ciência natural. Há uma ciência do Espírito e da Liberdade que aprecia os fatos e os atos segundo o dever ser; e há uma ciência da Natureza e do Determinismo que é a do mundo do ser. Elas não são antagônicas, não se excluem. Elas se completam e se influenciam reciprocamente, mas uma não pode ser reduzida à outra, como fazem os materialistas de um lado, os idealistas em campo oposto. É o vicio do unilateralismo que faz um MARX só ver a economia, ou um RATZEL só ver a geografia. Os objetivos da ciència do homem são distintos, mas a verdade integral é só aquela que tôdas conjuntamente alcançam. Seus processos são diferentes porque diferentes são as maneiras de apreciar idênticos objetivos. Ora, na história necessário é aplicar um processo integral. Em verdade 
que é a história senão o estudo dos fatos fundamentais da humanidade, dos atos desenrolados no tempo e no espaço a fim de realizar aquilo que deve ser? E para realizar o que deve ser, não atua o homem no que é, não se contrapõe ao que existe? não se afirma contra ou a favor do que é? $O$ homem se serve dos conhecimentos obtidos no determinismo do mundo objetivo para realizar os fins que a sua subjetividade livremente estabelece" ${ }^{4}$.

Tudo isso não foi repetido, sob roupagens várias, e a propósito de assuntos diversos, em outros trabalhos? $\mathrm{E}$ não deparamos a mesma inspiração fundamental em Pluralismo e Liberdades, ou então na última edição da Filosofia do Direito?'.

Tudo isso fica claro, agora, quando se abarca, numa visão retroativa, a obra realeana inteira. Mas quem reencete, desde os primeiros trabalhos, a marcha evolutiva que o autor descreveu, procurando "pôr entre parêntesis" o que veio depois, não poderá ter uma visão tridimensional do Direito, que surge, assim, como uma descoberta notável, enunciada em Fundamentos. Daí o dizermos que êsse livro, apesar de tôdas as limitações que hoje nele se reconhecem, e que o próprio autor, com aquela honestidade que o caracteriza, também não esconde, desempenha um papel decisivo na estrutura global da obra, e portanto na própria estrutura do pensamento juridico brasileiro atual ${ }^{7}$

De certo modo, portanto, trata-se de um livro que lança as bases de um novo ciclo evolutivo no pensamento do autor, aquêle que se abre para a realidade juridica com perspectivas novas, não obstante utilizando as premissas conquistadas na fase anterior. Esta, assim, deve ser considerada uma fase preparatória. Mesmo no que diz respeito à concepcão

4. Atualidades de um mundo antigo, Introdução, p. 14.

5. M. REALE, Pluralismo e Liberdade, São Paulo, 1962.

6. M. Reale, Filosofia do Direito, edição de 1966.

7 O Prof. REALE, mais de uma vez, nos tem dito que para reeditar os Fundamentos do Direito teria que pràticamente escrever um novo livro. 
do homem, da história, do próprio mundo, a fase que se desdobra, após Fundamentos, guarda peculiaridades extraordinárias, que a anterior não consegue prenunciar. Isso não quer dizer - convem repetir - que haja contradição entre ambas, ou mesmo discordâncias. Mas há diferenças fundamentais. A segunda assume características inteiramente independentes, conforme se pode ver, notadamente, em Pluralismo e Liberdade, que é onde o autor alcança a sua mais vigorosa expressão teorética. $O$ mesmo se diga, no que concerne ao aspecto pròpriamente jurídico, em relação a Le Dignitate Jurisprudentiae e à última edição da Filosofia do Direito, tendo em vista Fundamentos e alguns trabalhos que, de imediato, o seguiram.

V.

Mais importante, porém, do que a análise esboçada, e que outra coisa não quis indicar senão o papel que Fundamentos desempenhou na própria evolução do pensamento realeano, é verificar o que essa obra importou para o pensamento brasileiro, e notadamente para o pensamento que se desenvolveu sob as Arcadas.

Como já dissemos, pensamos encontrar-nos numa posição privilegiada para estabelecer comparações nesse sentido. Já fizemos alusão ao contraste que se estabeleceu no concurso de 1940, contraste êsse que teve por base as idéias ventiladas em Fundamentos. Pela primeira vez, provàvelmente, no país, mas sem dúvida alguma, nas Arcadas, o pensamento juridico mais atual era desdobrado aos olhos dos juristas e dos estudiosos na plenitude de suas perspectivas. Isso não quer dizer que, em outros concursos e em outras oportunidades, aspectos particulares do pensamento jurídico contemporâneo não tivessem sido, igualmente, considerados e mesmo aproveitados como fundamento para conclusões essenciais. A Faculdade do Direito, não obstan- 
te sempre mal compreendida, esteve sempre aberta às idéias novas, para delas recolher o que apresentam de útil e verdadeiro. Mas nas oportunidades aludidas, por fôrça das próprias exigências de especialidades, tinham-se em vista, tão só, implicações peculiares de certas doutrinas, nas esferas especiais do Direito Civil, do Direito Comercial, do Direito Constitucional, do Direito Penal, do Processo. Uma visão de conjunto, na plenitude de suas implicações, não chegara a ser feita.

As duas cadeiras, que poderiam ensejar oportunidade para uma tarefa dessa natureza, tinham sido até então ocupadas por mestres de tendência positivista, tomista, hegelianista, e que se mantinham rigorosamente dentro dos limites de sua visão pessoal. Verdade é que João Arruda procurara, de certa forma, dar uma visão de conjunto das várias concepções do Direito, inclusive algumas mais modernas, mas não tivera oportunidade de chegar aos momentos fundamentais do pensamento contemporâneo. Também não era menos exato que Mario Mazagão procurara, com precisão e clareza que hoje nos causam admiração, expor as teorias hegelianas sôbre o Direito, sem esquecer as idéias kantianas, mas não tivera tempo de desvendar os mistérios do pensamento posterior, inclusive daqueles que, prendendo-se ao pensamento do autor da Fenomenologia do Espírito, haviam dado impulso decisivo à cogitação filosófico-jurídica.

Certo, Vicente Rao, que como poucos juristas positivos é dotado de visão geral dos problemas juridicos, fazia incursões soberbas pelos temas gerais, quando expunha a Parte Geral do Direito Civil. Mas não the era dado estender-se muito, nem aprofundar indevidamente as suas pesquisas. E a nossa turma, a de 1944, se vira privada inclusive dessas sugestivas indagações, que teriam sido de utilidade inestimável, em virtude de haver sido o douto jurista afastado da cátedra, quando cursávamos ainda o primeiro ano, para a ela retornar sòmente depois, no segundo ano. 
A cadeira de Introdução à Ciência do Direito, essa sim, se prestaria, como se presta - e realmente está desempenhando èsse papel - a indagações amplas quanto ao pensamento jurídico atual, bem como a respeito de temas fundamentais de Teoria Geral. Mas o nosso mestre de então, espírito lúcido e profundo, preferia imprimir ao curso um caráter mais de técnica juridica, dando-lhe desenvolvimento adstrito ao direito positivo. Estava, provàvelmente, convencido de que o mais importante era levar ao espírito dos alunos certos dados técnicos, que sobrelevavam em interêsses à discussão ampla das teorias, com que aliás se mostrava intimamente familiarizado. Infelizmente para nós, não procurou, de viva voz, transmitir-nos o que se continha nas Leis fundamentais da evolução jurídica ${ }^{8}$, nem no papel do jurista na hora atual ${ }^{9}$. Nesses trabalhos, apesar de reduzida dimensão, segundo Grofredo Telles Junror, esboçavam-se as bases de uma doutrina inteira do direito.

Daquilo, que o atual catedrático de Introdução à Ciência do Direito qualifica como realismo jurídico, não nos foi dado nada perceber, pois de tais assuntos, infelizmente, êle não cuidou. Entretanto, como nos teria sido útil, no pórtico do curso jurídico, receber a memorável lição, que hoje todos admiramos, de que devemos buscar o direito nas coisas mesmas, na vida quotidiana, o que certamente teria evitado que andássemos transviados por outros jardins, para usar a sua formosa expressão! Nem tampouco pudemos haurir nada do seu utilitarismo, assim como não pudemos ter nenhuma idéia das suas concepcões gerais a respeito da justiça e do direito. Em grande parte, teria sido isso decorrência da moléstia, de que já então se ressentia, e que em breve iria afastá-lo da faculdade e dos alunos, a que amava extremosamente. Seria assim necessário aguardar a ascen-

8. Sôbre SPENCEr VAMPRÉ, consulte-se o curioso estudo que lhe dedicou o Prof. GoFremo Telles Junion, na Revista da Faculdade de Direito, v. 60 , p. 25 e seguintes.

9. Cf., a tal propósito, o trabalho do prof. GoFrEDo TEHLLes JUNIOR. 
ção à catedra de Gofredo Telles Junion, para que a cadeira se incumbisse no papel que lhe é naturalmente reservado, desvendando horizontes filosóficos e juridicos gerais ${ }^{10}$. E depois, de Alberto Moniz da Rocha Barros, que passaria a reger o curso noturno revelando-se aberto a tôdas as sugestões doutrinárias.

Outra oportunidade, de que deveríamos beneficiar-nos, seria o Direito Constitucional, incluido no segundo ano. Mas essa oportunidade estava pràticamente sacrificada, em virtude do regime, tipicamente discricionário, então vigente. Não havia mesmo ambiente para o debate amplo, sem fronteiras, das grandes idéias que agitavam os constitucionalistas, com implicações diretas na Teoria Geral do Direito, tal qual depois virificaríamos através do estudo das obras de Hauriou, de Léon Duguit, de Gaston Jèze, de Carl Schwitt.

A problemática jurídica, assim, embora de uma maneira inevitável e necessàriamente restrita, nas suas perspectivas fundamentais, nos foi apresentada por vias indiretas, através do Direito Penal, do Direito Processual e do Direito Social, mas isso mesmo, como se impunha, de modo forçadamente fragmentário, com intuitos introdutórios, e com indicações apenas indispensáveis para que nos afeiçoássemos aos temas centrais das disciplinas. Os profs. Basileu Garcia, Siqueira Ferreira e Cesarino Junior faziam mesmo, a tal respeito, uma verdadeira ginástica mental, desviando-se dos rumos a que estavam adstritos, para peregrinações que nos enlevavam, a setores por que a rigor não deveriam incursionar.

Numa situação semelhante, em que nem mesmo existia ainda uma cadeira de Teoria Geral do Estado, é fácil perceber o impacto que representou, para todos nós, uma cátedra que nos convidava a volver aos princípios, aos fundamentos mesmos do Direito, e que transformava em problema tudo o que, até então, nos parecera pacífico e tranqüilo. Recordâmo-nos bem, ainda, tal a impressão que experimentamos, da inquietação de que nos vimos possuido,

10. Cf. Gofredo Telles JR., Filosofia do Direito, v. 1. 
quando nos foi posto diante dos olhos, com uma evidência excepcional, a incerteza quanto ao conceito do direito. E daí por diante, com avidez extraordinária, todos nós nos vimos sủbitamente envolvidos numa sucessão de questões $\mathrm{e}$ num mar de teorias, que conflitavam entre si, a respeito de dados que antes pareciam insuscetiveis de qualquer contestação e de qualquer dúvida. Um enorme clarão se abria, sùbitamente, diante de todos nós.

Através daquela mole imensa de idéias, que jorravam do topo da cátedra de Filosofia do Direito, num desdobramento fecundo, uma convicção se apossava cada vez mais do nosso espírito e jamais dêle se desprenderia. O direito ganhava vida, ganhava consistência, ganhava concretitude. Deixava de ser a mera forma vazia, adiáfora, que parecera ser até então, para se impregnar de realidade, de contextura. Mas logo, no nosso arrebatamento, ouvimos a advertência do Mestre, de que não transformássemos a realidade jurídica em pura realidade fática, coisificando o que tinha, como ponto essencial, uma dimensão valorativa. Essa advertência, que ouvimos ainda nos bancos acadêmicos, nos tem sido, no correr dos anos, de uma utilidade extraordinária. Mais tarde, naturalmente, iríamos compreender melhor, através do contacto com as idéias husserlianas e as lições de Difrhey e de Windelband, a razão profunda dessa advertência. Nela está, porém, presente o que de mais profundo existe, o que de mais sugestivo se vislumbra numa concepção do direito que procure fugir aos equívocos do formalismo, mas que também evite descambar para os exageros do sociologismo. Hoje, mais do que em qualquer outro momento, sentimos a profundidade com que o prof. Miguel Reale enfoca o problema, indo direto à identificação do ponto sensivel do objeto jurídico, indo à essência mesma do juridico.

Tudo isso desabou sôbre todos nós, na época, com um impacto tremendo. Pela primeira vez tínhamos oportunidade de ver desdobrar-se diante de nossos olhos, em tôda a extensão, a problemática inteira do direito, na riqueza 
imensa e variegada que lhe imprimia o pensamento moderno, em tôdas as suas manifestações. 0 direito assumia uma estrutura diferente, se vinculava ao homem, na multiplicidade de suas atuações, adquiria aquilo que a filosofia moderna sublinhava como historicidade e concretitude. A própria idéia de justiça, tradicionalmente tida como abstrata, ganhava objetividade concreta, consistência histórica, dimensão cultural, embebendo-se de historicidade. As coisas, de certa forma, desciam do céu para a terra. $E$ a pessoa, que se inseria no processo histórico, tornava-se algo real!

Éramos levados, espontâneamente, a reexaminar, à luz dessas idéias, problemas que já tínhamos como assentes, e definitivamente assentes. Haja vista o que ocorria em relação ao problema da interpretação, que passava a adquirir perspectiva inteiramente nova.

Onde, todavia, a visão mais se enriquecia, e punha em cheque a nossa argúcia, era quando se cogitava de uma visão da realidade jurídica.

Nessa fase do curso, Reale ainda não lograra uma fórmula definitiva para a sua concepção do direito. A sua hoje famosa teoria tridimensional do direito, a essa altura, estava ainda nos primórdios, tinha uma feição marcadamente estática, bem diversa do dinamismo que hoje a caracteriza.

VI.

Não obstante isso, já constituía então um desafio direto às concepções tradicionais e mesmo às concepções modernas, que circulavam com maior ou menor insistência, especialmente fora das Faculdades de Direito. REale surgia, no ambiente jurídico, não só em oposição às posições tradicionais, mantidas pelos juristas, mas também àquelas, que, fora dos círculos jurídicos, procuravam absorver a perspectiva jurídica, com o propósito de demonstrar a sua incon- 
sistência e deficiência. Reale, divergindo dos primeiros, repudiava também os segundos. A sua atitude era a de demonstrar que a jurisprudência tinha o vigor necessário para sobreviver e que a ciência jurídica podia, desde que mudasse os rumos que até então seguira, vencer as suas próprias dificuldades, e desincumbir-se a contento da tarefa que, no contexto do saber humano, lhe era reservada. Surgira assim, dentro do círculo pròpriamente jurídico, uma reação ao anti-jurídico, àquelas tendências que procuravam eliminar a perspectiva jurídica, em proveito de outras perspectivas, notadamente as de caráter sociológico.

Com veemência, com riqueza de argumentação, combateu o sociologismo, e grande parte de sua obra definitiva reproduz, com abundância de dados doutrinários, essas primeiras elaborações. Fê-lo, todavia, não pelo gôsto de salvar a jurisprudência, por uma questão de bairrismo científico, mas porque estava plenamente convencido - e o evidencia de maneira insuperável de que a jurisprudência tem uma perspectiva própria, uma razão de ser, um objeto formal, inconfundível com o de qualquer outro ramo do saber humano. O sociologismo, desde o da primeira hora até o de última hora, não soube ver isso, e por essa razão é que se preocupou em absorver o direito, desnaturando-o. A verdade, entretanto, é que a jurisprudência tem uma perspectiva própria, uma maneira peculiar de considerar a realidade jurídica, inconfundível com qualquer outra. Essa maneira peculiar, específica, de encarar a realidade juridica, é que dá autenticidade à jurisprudência.

Essa perspectiva se vincula, todavia, a uma concepção da realidade jurídica que se não confunde com outra qualquer. "O Direito - diria êle, mais tarde, em sua Filosofia do Direito - não pode ser reduzido, a nosso ver, a um sistema de normas concebidas como puros juizos de dever ser, erradicados do processo histórico social em cujo âmbito se constituem e adquirem significado, mas, nem por isso, deixa de haver um aspecto lógico fundamental na consideração da 
Jurisprudência" (4. a edição, p. 271). E com mais precisão ainda, acentuaria:

“O filósofo do direito, o sociólogo e o jurista não podem deixar de estudar o Direito na totalidade de seus elementos constitutivos, na tridimensionalidade de sua contextura, embora possam e devam ser distintos os respectivos prismas ou modos de pesquisa. Cada grupo de estudiosos cuidará, é claro, mais dêste do que daquele outro momento da experiência jurídica, mas deverá determinar sempre o significado autêntico de seu objeto de indagação em função dos outros dois. Sem essa referência aos demais, um fato da experiência jurídica não poderia ser lògicamente concebível, ou como fato jurídico (seria mero fato jurídico indistinto ou indiscriminado), ou como norma jurídica (seria simples norma ética), nem mesmo como valor de interêsse para o mundo do Direito" (Idem, Capítulo xxxiv).

Essa concepção já se acha esboçada na fase inicial. Entretanto, com o correr dos anos e o aprofundamento da meditação, vai adquirindo uma dinamicidade que antes não possuia, vai-se impregnando de um sentido dialético predominante.

Para o aspecto que, a esta altura, nos interessa, o que importa sobretudo é salientar que REALE dirigiu uma advertência fundamental aos sociólogos, bem como aos juristas de formação positivista e aos naturalistas de todos os matizes, pondo à mostra que não era possivel reduzir o direito a processos puramente causais, sob pena de despojá-lo do que nêle havia de mais específico. Assim, não era concebível uma explicação exclusivamente sociológica do direito, abstraindo de tôda e qualquer outra perspectiva, como pretendiam certas correntes sociológicas. $\mathrm{E}$ isso porque essa tendência redundava no mesmo exagêro das demais, reduzindo o direito a mero fato, o que importava na pura negação do direito. 
VII.

Vista assim, do ângulo que acabamos de apresentar, não teria a obra de Reale, já nessa primeira fase do seu desenvolvimento, um alcance nacional? Tristão dE ATAíde, quando, ao entrar em contacto com Fundamentos do Direito, a apontara como uma obra destinada a contribuir para a renovação dos estudos filosófico-jurídicos entre nós, não vaticinara algo certo? Estamos plenamente convencido de que sim.

A mentalidade então dominante, nas Arcadas, refletia, de certo modo, a situação geral existente, em matéria de direito, no país inteiro, conforme já salientamos e procuraremos melhor demonstrar a seguir.

A par de remanescentes do positivismo, existiam representantes naturalistas de todos os matizes. E a êles se aliavam os sociologistas das várias origens. Mesmo aquêles, que ocupavam cátedras universitárias, em faculdades de direito, não fugiam a essas orientações. Edgard Sanches, Pontes dE Miranda, Hermes Lima, Djacir Menezes, Carlos Campos, Eduardo Espínola, Queirós lima, Clovis Bevilaqua, Francisco Campos, Mario Mazagão, Spencer Vampré, Vicente Rao, Nelson Hungria, Valdemar Ferreira, Hahnemann Guimarães, que compunham a vanguarda do pensamento jurídico de então, e cujas idéias exerciam real influência entre mestres e discípulos, entre juristas e advogados, sem esquecer promotores e magistrados - todos êles, mais acentuadamente ou menos acentuadamente, se filiavam a orientações que, à falta de uma designação melhor, se poderia qualificar de naturalista ${ }^{11}$. Mesmo o mais influente

11. Cf. Pedro Lessa, Estudos de Filosofia do Direito; JoÃo ARrUDA, Filosofia do Direito; Pontes de MrRanda, Ciência Positiva do Direito; HeRmes Lima, Introdução à Ciência do Direito; DJACIR MENEZES, Introdução à Ciência do Direito; SPÍNola, Tratado de Direito Civil e Sistema de Direito Civil; QueIRoz LIMA, Sociologia Jurídica; Clovis Bevilaqua, Juristas Filósofos, Esboços e Fragmentos, Teoria Geral do Direito Civil. 
dos nossos juristas, que era Clovis BevilaQua, não se afastava dessa linha. Havia, naturalmente, diferenças sensiveis entre vários dêles, que compunham correntes independentes entre si. Ninguém poderia confundir as idéias de Pontes de Mrranda e Duacir Menezes com as de Hermes Lima, Éspinola ou Queirós Lima. Mas substancialmente tinham pontos de contacto íntimo, e a concepção geral que os inspirava estava muito mais próxima do que êles próprios estariam inclinados a admitir.

"O sociologismo jurídico - acentua Reale - traduz uma exacerbação ou exagêro da Sociologia Jurídica, pois esta, quando se contém em seus justos limites, não pretende explicar todo o mundo jurídico através de seus esquemas e leis, até ao ponto de negar autonomia à Jurisprudência, reduzindo-a a uma arte de bem decidir com base nos conhecimentos fornecidos pelos estudiosos da realidade coletiva". (Idem, p. 380). Essa afirmação viria depois, é certo, em forma escrita, mas na verdade já estava expressa nas primeiras lições, nas primeiras mensagens que dirigia aos estudiosos. Nós a recolhemos sôfregamente, com os nossos colegas de então, quando êle expunha, da cátedra, o sociologismo jurídico notadamente o de tendência durkheiniana. Naquela ocasião, ainda não lhe podíamos apreender, com a exatidão devida, o verdadeiro alcance. Este desbordava, porém de muito, o âmbito puramente estudantil. Tinha alcance universitário. Tinha alcance nacional. Era uma tomada ae posição polêmica, um grito de reação e de renovação. No fundo, conforme já acentuamos, representava um anátema, que alcançava diretamente os positivistas, mas que na verdade alcançava determunistas de todos os matizes, os naturalistas de tôdas as orıgens. Ȧ atenção se volvia, particularmente, para os sociólogos, porque êstes, ao impulso de certos preconceitos então em voga, pretendiam estabelecer um verdadeiro monopólio em relação aos fenômenos humanos, negando-se a compartilhar o estudo da sociedade com qualquer outro processo científico. A dignidade da jurisprudência, a dignidade científica da jurisprudência, o direito à 
subsistência da ciência jurídica, como ciência, se colocava assim, por fôrça de uma posição nova, no âmago de uma concepção que deitava raízes em uma ampla concepção do homem, do mundo, da sociedade, infensa às explicações naturalistas.

Não representava isso um acontecimento extraordinário, dentro como fora da Faculdade, no âmbito das Arcadas e fora das Arcadas? A repercussão foi imediata, especialmente no espírito dos jovens que tiveram a fortuna, como nós, de recolher primeiro essa mensagem espiritual, que acenava com algo novo, com algo que se enraizava profundamente no homem, na sociedade e na história.

Já dissemos que tudo isso desabou sobre nós, adolescentes de então, com um impacto extraordinário. E assim foi, enı lodo o rigor do têrmo. Vivíamos todos mais ou menos imbuidos de positivismo, se não filosófico, pelo menos jurídico. É esse aliás um ponto que algum dia deverá merecer atenção especial dos estudiosos. A maioria dos nossos juristas, mesmo aquêles que repelem as premissas positivistas e que apregoam antipositivismo, sem o notar, quando tratam de assuntos jurídicos, adotam posições positivistas. REALE nos chamou a atenção para tudo isso e nos ensinou a fazer uma revisão completa dos temas que até então havíamos ingerido, sem crítica alguma, e com adesão fácil. O efeito, como acentuamos, foi decisivo. Não só no que diz respeito aos problemas jurídico-positivos, pròpriamente ditos, mas também aos temas jurídicos mais gerais. Havia uma preocupação geral em recorrer à sociologia, em busca de explicação para os fenômenos jurídicos. De certo modo, eram duas as posições que se abriam diante de nós - sociologismo ou tomismo. Não se vislumbrava nada diferente. Não havia outra via a seguir. O próprio marxismo, que posteriormente alcançaria intensa divulgação, não encontrava maior repercussão e mesmo entre os seus adeptos não se afirmara com consciência plena, em relação aos problemas jurídicos e notadamente, o que era de importância maior, em relação aos problemas jurídicos nossos. Para 
isso contribuía a carência de indagações, entre os próprios corifeus do marxismo, com relação aos temas fundamentais do Direito. O que nos restava portanto eram as duas posições já indicadas, que por vários motivos não satisfazia à maioria. Reale veio mostrar a possibilidade de uma terceira posição, que fugia às dificuldades das duas e permitia ao jurista afirmar-se, com autenticidade, entre os que se apresentavam como ponta de lança do pensamento atual.

Não resta dúvida que a maioria, se não mesmo a totalidade, deixou os bancos acadêmicos sem ter conseguido assimilar grande coisa, em virtude de deficiências próprias, da Filosofia do Direito. Mas é inegável que de lá saímos todos com algo mais precioso do que a familiaridade com todos os sistemas - a plena consciência da temática juridica, a posse de um novo método e o estímulo imperecível de uma pesquisa nova, a respeito do direito. Era fora de dúvida que para todos nós um horizonte novo se abrira e iríamos, sem dúvida, procurar alargá-lo ainda mais, na carreira que então se iniciava.

O nosso meio jurídico a essa época, sem exageros, respirava ainda a atmosfera que criara a Escola de Recife, pois não se podia esquecer que Clovis era, autênticamente, um filho espiritual da oportuna reação de ToBIAs, o mesmo ocorrendo com os demais. A qualificação, sob vários aspectos, se ajustava a Pontes de Mrranda, cuja obra, quer como jurista-filósofo, quer como sistematizador de direito, se embebia dos mesmos principios.

E São Paulo tinha, a tal respeito, uma tradição provecta, muito mais densa e profunda, do que parecera à maioria dos analistas do nosso pensamento. Basta citar dois nomes, que foram objeto, ùltimamente, de estudos cuidadosos, para que se tenha uma idéia precisa do que estamos dizendo - Alberto Sales e Paulo Egídio ${ }^{12}$. Cada

12. Cf. os formosos estudos de Luís Washington Vita, Alabrto Sales, São Paulo, 1963; Migued Reale, A Filosofia em São Paulo, São Paulo, 1963. 
um a seu modo, procurou trazer para as ciências do homem, inclusive o direito, aquêles princípios naturalistas que a Escola do Recife propagara pelo país inteiro.

A verdade, todavia, é que a Escola do Recife trazia dentro de si mesmo algo mais, que passara inteiramente despercebido aos estudiosos contemporâneos e aos pósteros, e que entretanto assumia significação extraordinária. 0 culturalismo, que era uma das facetas mais expressivas do pensamento de ToBIAS BARRETo, fôra pràticamente posto à margem, ou pelo menos esmaecera, diante das demais idéias, especialmente as haeckelianas, que despontavam com um vigor polêmico excepcional da pena do bravo sergipano. Por curioso que possa parecer, e que se reveste de importância sem dúvida decisiva, a reação às idéias da Escola do Recife surgiria do seu próprio seio, daqueles que em grande parte se tinham nutrido dos seus princípios, como é o caso de Farias Brito, em cujo pensamento as correntes culturalistas teriam uma repercussão notável, inclusive no que se refere ao direito ${ }^{13}$.

Apesar porém da reação espiritualista, e não obstante a imensa influência que FARIAS BrITo passara a exercer, notadamente no setor da filosofia e mesmo da literatura ${ }^{14}$, com reflexos na política, o pensamento jurídico se mantivera fiel, nas suas expressões fundamentais, às diretrizes que lhe tinham traçado a Escola do Recife.

A nossa tradicional Escola não ficou livre dêsse clima. Aliás, como acentua Irineu Strenger, na tese com que disputou e conquistou a livre-docência de Filosofia do Direito, desta Faculdade, houve, de certa forma, nas Arcadas, manifestações que importam em verdadeira antecipação ao germanismo da Escola do Recife, embora, naturalmente,

13. A tal respeito, cf. MIgUer ReALe, Horizontes do pensamento jurídico e Teofllo Cavalcanti FiLho, $O$ Pensamento Jurídico de Farias Brito.

14. Tristāo de AtaIde vê no simbolismo uma manifestação em que FARIAS esteve presente. Veja-se Literatura Brasileira, vol. III. 
com propósitos e diretivas bem diferentes ${ }^{15}$. Mas é importante notar o fato, para ressaltar como o ambiente cultural da Faculdade de Direito foi sempre aberto às especulações de tôda natureza, e jamais criou barreiras ao livre trânsito de ideologias.

No que se refere, especificamente, às idéias positivistas, é indiscutível que, desde muito cedo, elas repercutiram em nosso ambiente acadêmico, aqui encontrando, notadamente na mocidade estudantil, seguidores entusiastas. "Tal a penetração da Filosofia Positiva, na FacuIdade de Direito de São Paulo - adverte Ivans Lins - na década de 1880 a 1890 , que o prof. dr. José Maria Correia de Sá e Benevides, católico e tomista irredutível, quase não dava uma aula sem objetar algum aspecto da obra de Comte, embora fôsse o Direito Romano a matéria sôbre a qual devia discorrer. Na trigésima nona lição do seu curso de Direito Romano, assim se referia o dr. Benevides ao Positivismo: "Positivismo é uma destas coisas que andam por aí espantando a todo mundo; positivismo não tem nada de novo, nada absolutamente senão o nome, não é senão o pedantismo da fórma e a audácia das conclusões, mas, no fundo, positivismo é, afinal de contas, Bacon, é, afinal de contas, Aristóteles, com suas variantes" 16 .

15. IRINEU STRENGer mostra, em seu trabalho, como RiBAs foi dos primeiros a se preocuparem, entre nós, pela ciência jurídica alemã. De maneira especial, volveu êle a atenção para a pandectística germânica, cuja importância científica soube compreender e ressaltar. Cf. Da Dogmática Jurídica, capítulo V.

16. Ivan I Ins, História do Positivismo no Brasil, p. 138 . o prof. José Maria Correia de Sá E Benevides, em artigo que publicou no Correio Paulistano e que se pode ler, agora, no vol. 9, tomo II, das Obras Completas de Rui Barbosa, faz a seguinte observação, a respeito do trecho citado: "Este periodo foi escrito sem gramatica e confusamente reproduziu o que disse. Em substancia o que anunciei na preleção foi que a propaganda da filosofia positivista entre nós já estava espantando a todo o mundo e despertando nos jovens algum entusiasmo; que não tinha razão de ser, porque o metodo positivista era no fundo o metodo fundado por Aristoteles e organizado siste- 
Também já deviam estar em voga, entre nós, os livros de Darwin, Spencer e Haeckel, tanto assim que Julio Ribeiro, em 20 de maio de 1885, indagava "que filosofia é a do dr. Benevides, que esfalfa-se ridiculamente a refutar na aula Comte e Darwin, Spencer e Haeckel, malbaratando um tempo que poderia muito melhor aproveitar?" 17

SPEncer VAMpré, em sua magnifica Memória da Faculdade de Direito, faz observação idêntica a respeito da divulgação do positivismo no ambiente das Arcadas, sem poder esquecer que êle próprio refleteria essa influência, com manifestações spencerianas ${ }^{18}$.

Aliás, não demoraria a que o positivismo adquirisse uma tribuna permanente, através da cátedra de Almeida NogueIra, que se deixara influenciar por muitos aspectos da filosofia de Сомте.

Não é por outra razão, que o primeiro pesquisador do desenvolvimento das idéias positivistas no Brasil, Joño $\mathrm{CA}_{A-}$ milo de Oliveira Torres, ao fazer um levantamento da influência de Comte em nosso Estado, proclama que “A Faculdade de Direito de São Paulo foi um dos grandes centros culturais do Brasil durante o Imperio. Não havia novidade no mundo das idéias que não tivesse repercussão sob as Arcadas. Como seria natural, o Positivismo teve tambem grande repercussão aí. Mas, graças às condições sociais peculiares a uma escola de direito, dominou ali o positivismo dissidente, que se apresentou caracterizado por um acentuado criticismo no plano logico e um republicanismo de aspecto nitidamente revolucionario, no plano das realidades politico-sociais. Desta escola sairam Silva Jardim, Deme-

maticamente por Bacon, e as idéias, que se diziam novas, formuladas pela filosofia positivista, só tinham a novidade da forma, que era pedantesca, e a audacia das conclusões."

17. A pud IVAN Lins, op. cit., p. 139.

18. Os prof. PaUlo Barbosa de Campos filho e Moacir lobo DA Costa nos revelaram que, quando alunos de VAMpré, tiveram oportunidade de ouvir preleções do Mestre, em que êle expunha com grande simpatia as idéias de SPENCER. 
trio Ribeiro, Julio de Castilhos, José Leão, Americo de Campos.. Como de lá saiu Lafayette, o kantiano de Vindiciae." 19 .

A influência positivista, de resto, consoante ressaltam os historiadores, se fêz sentir nas Arcadas, notadamente, através de inúmeras publicações, que se encarregaram de divulgar amplamente as idéias de Comte.

Essa geração, que se formou no ambiente positivista então dominante na Faculdade, iria ter uma influência decisiva no país, através de alguns representantes de nível intelectual dos mais elevados. Basta referir Julio de CastulHo, Borges de Medeiros, Silva Jardim, Lucio de Mendonça, Alberto Sales, Joño Pinheiro, Rodrigo Otávio, Rivadavia Correa, Alcides Maia, Basilio Magalhães, Vicente de Carvalho, Pedro Lessa, Demetrio Ribeiro, José Leão e Americo de Campos.

Nas Arcadas, dois mestres dos mais eminentes, que exerceram, sem dúvida, influência no espírito da juventude que os ouvia, continuaram, da cátedra, a transmitir idéias em que essa influência subsistia, como é o caso de PEdro Lessa, primeiro, e de JoÃo Arruda, depois. Em grande parte, as gerações que passaram pelas Arcadas, nos primeiros vinte e cinco anos do corrente século, formaram a sua mentalidade sob a influência dêsses mestres e também de outros mestres, notadamente de Direito Penal, que não escondiam a sua predileção pela corrente positivista.

Os escritos, que nos deixaram os dois professôres que exerceram a cátedra de Filosofia do Direito em nossa Escola, e que ainda hoje são dignos de meditação e estudo cuidadoso, põem à mostra a orientação uniforme fundamental existente entre ambos, não obstante as indiscutiveis e numerosas discrepâncias que os distinguem.

Para o que tenho em vista, porém, basta assinalar o caráter geral das idéias que nutriam, e que foram responsáveis, indiscutivelmente, pelo aspecto mais saliente da men-

19. J. C. Oliveira Torres, O Positivismo no Brasil, p. 198. 
talidade de nossa Escola, até por volta de 1940, quando se realizou o concurso para o provimento da cátedra de Filosofia do Direito. A tal ponto essa influência se exercera, que em dado momento, considerou-se a Cadeira de Filosofia desnecessária, no curso de bacharelado, porquanto a Filosofia, segundo a concepção positivista, nada mais era do que uma síntese dos conhecimentos científicos, levado a um grau de generalização mais acentuado.

\section{VIII.}

Num trabalho da natureza do que estamos empreendendo, de reconstituição da mentalidade dominante em nossa Escola, em determinado período de sua existência, são particularmente importantes os dados atinentes aos programas das cadeiras de determinados professôres, notadamente aquêles que tiveram uma influência maior no espírito dos estudantes e no ambiente acadêmico, bem como o exame direto das obras que elaboraram e deixaram para a posteridade.

Com êsse objetivo, cabe, antes de mais nada, verificar a atuacão de Pedro Lessa, que incontestàvelmente foi, dos mestres do final do século passado e do início do corrente, um dos que mais funda marca de sua passagem deixaram na Faculdade de Direito. Em relação a Pedro Lessa, ademais, há uma circunstância que o coloca em situação particularmente importante, para os fins que aqui se tem em vista _ é a de que foi êle, pràticamente, o primeiro a exercer a cátedra de Filosofia do Direito da Faculdade, porquanto o mestre que o antecedeu, o prof. Brasilio Augusto Machado de Oliveira, nela não permaneceu mais de um ano, de 1890 a 1891. Pedro Lessa assumiu-a em 1891, ficando à sua frente até 1907 , tendo uma atuação notável. Retrata-o, como mestre, Valdemar Ferreira, baseado em VAMPRÉ, desta maneira expressiva - "Professor insigne, de uma cultura profunda, foi, verdadeiramente, o criador 
da cadeira de filosofia do direito, nos cursos juridicos. . Era dos professôres maìs acatados pelos moços" 20 .

A sua formação, como estudante, coincidiu com a ampla circulação das idéias positivistas, em São Paulo, e notadamente nas Arcadas, apesar da firme reação de Sá Benevides, que exercera, por vários anos, a cátedra de Direito Natural.

O programa de ensino, elaborado pelo próprio Pedro Lessa, já reflete a nova mentalidade que passara a vigorar sob as arcadas e a que êle emprestaria o vigor de sua personalidade e de sua inteligência.

Começava com uma parte introdutória, na qual expunha as principais teorias sôbre o direito, iniciando-se com as concepções jurídicas dos gregos, dos jurisconsultos romanos, para depois passar ao que denominava de filosofia teológica e atingir o kantismo, o krausismo, o utilitarismo de Bentham, a escola histórica e, finalmente, Inering. Entretanto, onde mais sensível se apresentava a sua orientação era na parte, que denominava geral, que se abria com uma noção típica de filosofia, desdobrando-se na explicação das três posições fundamentais - a teológica, a metafísica e a positiva. Igualmente, na parte atinente ao direito, as mesmas idéias se refletiam ${ }^{21}$.

O modo de expor essa matéria, e o colorido que a ela emprestava PEdro Lessa, são fàcilmente verificáveis através da leitura de seus Estudos de Filosofia do Direito ${ }^{22}$, que, como se sabe, e êle próprio o revela, são reproduções, ampliadas, de lições que professou na Faculdade.

Tôdas elas, consoante êle próprio sintetiza, se orientavam por uma idéia capital. - "Não tendo podido, jamais compreender, desde os primeiros anos do meu tirocinio academico, a confusão do direito com a religião, que faziam

20. Revista da Faculdade de Direito de São Paulo, v. 24, p. 90.

21. Cf. Faculdade de Direito de São Paulo, Programa de Ensino da $10^{\circ}$ cadeira do $10^{\circ}$ ano, Filosofia do Direito, apresentado pelo catedrático, dr. PEDRo Lessa, São Paulo, 1901.

22. Pedro Lessa, Estudos de Filosofia do Direito, São Paulo 1912. 
escolas muito em voga naquela epoca, nem a vaga, balofa e incolor explicação do direito, contida nas doutrinas metafísicas, dentre as quais a mais propagada em nosso pais era então a de Krause, exposta por Ahrens, esforcei-me sempre por estudar esse fenomeno social pelos mesmos processos logicos, pelo mesmo metodo, composto exclusivamente da indução e da dedução, por que se estudam os fenomenos do dominio das outras ciencias, sociais e inferiores" 23 .

Para Lessa, o processo lógico, que conduziria ao estudo científico do direito, seria aquêle decorrente da concepção positivista, em conformidade com o qual "as ciências sociais se devem estudar pelo mesmo metodo por que se estudam as ciências inferiores"24 e que outro não são senão os métodos dedutivo e indutivo, aplicados conjuntamente, para que se possa alcançar os principios gerais. Consoante insistentemente acentua, às ciências humanas, e entre elas figura a jurisprudência, devem ser aplicados, para que alcance a indispensável dignidade científica, o mesmo procedimento que se reserva para as ciências naturais, nas quais os resultados alcançados foram verdadeiramente inestimáveis. Pedro Lessa, ao longo de tôda a sua fecunda carreira, se manteve sempre fiel a essa posição fundamental, que se inspirava, diretamente, na corrente positivista. Entretanto, consoante acentuam todos os seus críticos, e não obstante a sua afinidade com essa corrente de pensamento, a ela não se escravizou, assumindo, a muitos respeitos, a posição não só independente mas original.

Já Reinaldo Porchat, no curioso estudo que dedicou ao "Pensamento Filosófico no Primeiro Século da Academia" 25 , salienta, certeiramente, que LEssa, embora tenha formado o seu preparo "nos moldes filosoficos da doutrina

23. Op. cit., V.

24. Pedro Lessa, Estudos de Filosofia do Direito, Metodologia Jurídica.

25. Reinaldo Porchat, $O$ Pensamento Filosófico no Primeiro Século da Academia, in Revista da Faculdade, v. XXIV, p. 367. 
de Augusto Comte, não se deixou entretanto escravisar pela ortodoxia positivista"26.

Outro analista da obra de Lessa, o prof. Miguel Reale, por isso mesmo, prefere filiá-lo ao naturalismo, em sentido genérico, e ainda assim sublinhando as suas características independentes e mesmo originais ${ }^{27}$.

De qualquer forma, o que parece fora de dúvida é que LESSA se manteve fiel aos ideais positivistas, pelo menos no que de mais característico havia naquilo que se pode denominar de espírito dessa filosofia. $\mathrm{E}$ com isso, inegàvelmente, contribuíu de forma decisiva para instaurar, no ambiente das Arcadas, a mentalidade positiva, que nela haveria de prevalecer, até por volta de 1930 , quando novas manifestações começaram a surgir, notadamente no seio da mocidade acadêmica, que partilhava de outras idéias e de outras aspirações. Era uma geração nova, que se alimentava de idéias também novas, bem diferentes daquelas que haviam inspirado a mocidade acadêmica, à época em que Lessa cursava a velha e sempre nova Academia.

Em 1910, quando o prof. JoÃo Pedro da Veiga Filho substituía LESSA, na regência da cadeira, que ainda se incluía no programa do $10^{\circ}$ ano, as diferenças não eram sensíveis. o espírito que inspirara a organização do curso do eminente antecessor ainda persistia, firmemente. O programa compreendia uma parte geral, onde se ministrariam noções acerca do direito e da filosofia, para depois o expositor poder passar à explanação das escolas filosóficas, numa catalogação que lembra, claramente, a sistematização comtiana. Vinham depois as inevitáveis indicações acerca das três direções da filosofia (a teológica, a metafísica e a positiva). A seguir, o exame da evolução jurídica, atendendo já às escolas evolucionistas ${ }^{28}$.

26. Idem, idem.

27 Miguel Reale, Filosofia em São Paulo, p. 120.

28. Programa de ensino de Filosofia do Direito, para o ano de 1910, organizado pelo prof. dr. JoÃo PEDRo DA VEIGA Filho, São Paulo, 1910. 
Mais acentuado ainda, se revelava então o espírito positivista, no setor do Direito Criminal, através do magistério do prof. CÂndido Mota. Foi êle, consoante o testemunho de Reinaldo Porchat, quem primeiro fêz circular na academia as idéias propugnadas por LomBroso, imprimindo ao desenvolvimento do seu curso uma orientação caracterìsticamente positivista. O exame do seu programa, entretanto, revela quão exagerada foi a posição assumida pelo saudoso mestre, convertendo o Direito Penal em uma espécie de Criminologia, que se confundia, por sua vez, em uma antropologia de tipo lombrosiano. Aliás, o curso, de acôrdo com o delineamento que lhe traçou o douto mestre, ostentava a designação inicial de Criminologia, exigindo a sua definição, com a discriminação dos fatôres da criminalidade, entendidos êstes, fundamentalmente, nos aspectos endógenos, embora não esqueça também as implicações de ordem sociológicas ${ }^{29}$.

É curioso observar como, na mesma época, a outra cátedra de Direito Criminal, confiada ao prof. José Mariano Correa de Camargo, imprimia ao curso orientação inteiramente diferente, atendo-se mais àquelas características que compõem a denominada Escola Clássica ${ }^{30}$.

Não discreparia Joño Arruda, o douto professor que, em 1911, assumiria a cátedra de Filosofia do Direito, da orientação até então imprimida ao curso. E o que se depreende, por uma parte, do seu programa de ensino, e por outro, de suas preleções, que não faz muito foram reeditadas pela Editôra Saraiva ${ }^{31}$. Nêles, em suas linhas fundamentais, estão presentes as notas essenciais ao espírito positivo, que em sua época, ainda se mantinha vivo nas Arcadas, prolongando-se, como já acentuamos, em suas manifestações, notadamente no direito positivo, até época posterior. $\mathrm{O}$ mesmo espírito, as mesmas diretrizes se fizeram

29. Prof. CÂNDIDO Mota, Programa de Direito Criminal, 1910.

30. Prof. José Mariano Correa de Camargo Aranha, Programa de Direito Criminal, 1910.

31. Prof. JoĀo ArrudA, Programa de Filosofia do Direito, 1911. 
sentir ainda em época posterior, através do próprio JoÃo ARruda, que em 1931 exercia a cadeira de Introdução à Ciência do Direito, deslocada que fôra a de Filosofia, do Curso de Bacharelado para o de Doutorado ${ }^{32}$.

SPEncer Vampré, não obstante não se colocasse na mesma linha ideológica do seu antecessor, dela discrepando em pontos essenciais, nem por isso imprimia ao seu curso um desenvolvimento de grandes perspectivas ou mesmo de inteira autonomia com relação à corrente anterior. Ficara prêso a uma orientação quase que estritamente técnica, mais preocupado com os instrumentos necessários ao manejo do direito positivo do que pròpriamente com os princípios gerais informadores do direito. Isso é claramente perceptível no seu programa de ensino. Temos presente o que foi formulado para o ano de 1938, que é bem característico da sua orientação.

Cuida, em primeiro lugar, do direito e das leis, para ater-se ao que seja lei, passando logo à distinção das várias modalidades de direito, entre as quais não esquece de colocar o direito natural. A seguir, vêm as conceituações de direito subjetivo e objetivo. Após, cuida das inter-relações entre as instituições jurídicas e as instituições sociais, entre o direito e a moral, o direito e os costumes, com as religiões, para, depois, enveredar firmemente para noções de direito positivo, em suas múltiplas manifestações ${ }^{33}$.

Guardamos ainda recordação mais ou menos precisa de suas lições, que ouvimos em 1940, e lembrâmo-nos de que se mantinha estritamente fiel a êsse programa. Fazia explanacão simples, acessível aos iniciantes, mas atendo-se rìgidamente ao propósito de apetrechá-los para o acesso ao direito positivo.

Do prof. Moacir Lobo da Costa, ilustre livre-docente de Direito Processual Civil, de nossa Faculdade, recolhemos

32. Prof. JoÃo ARRUdA, Programa de Introdução à Ciência do Direito, 1931.

33. Prof. Spencer VAMPré, Programa de Introdução à Ciência do Direito, 1938.

UNIVERSTOADE DE SAOPROLO

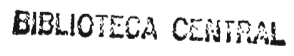


também o testemunho de que, em fase anterior, quando VAMPRé se encontrava na plenitude de sua capacidade intelectual e de sua energia, não dava ao seu curso colorido diferente daquele que conhecemos embora, como já registramos, intercalasse às vêzes noções gerais, de inspiração spenceriana.

Bem diferente, todavia, jả era, a essa época, a orientação imprimida ao Direito Penal, que adquirira aspectos autônomos, tomando feição mais consentânea com o seu caráter de ciência humana, e que se libertara acentuadamente das premissas positivistas. Mesmo aquêles, como o prof. NoÉ AzEvedo, que se tinham formado no ambiente carregadamente positivista de nossa Faculdade, já sentiam o sôpro de ventos novos, que vinham de diferentes direções.

Seria, entretanto, conforme já acentuei, necessário aguardar a ascenção do prof. Gofredo Telles Junion à Cátedra de Introdução à Ciência do Direito, para que esta se libertasse plenamente das premissas positivistas, a que ficara jungida, desde o seu nascimento. Com o novo titular, adquiriu ela plena autonomia em relação às orientações anteriores, tornando-se sensivel às novas correntes de pensamento, que soube o ilustre professor conciliar com a filosofia clássica. A cadeira, ao mesmo tempo, assumiu uma feição diferente, volvendo as atenções para os grandes temas concernentes ao fundamento, à validade, à eficacia do Direito, sem esquecer as premissas de caráter puramente filosófico, que são ministradas largamente aos alunos, por consideradas indispensáveis à compreensão exata do direito positivo. A tal respeito, são bastante ilustrativos os enunciados dos pontos do programa organizado pelo ilustre professor, bem como o seu livro, ùltimamente aparecido, e que se intitula Filosofia do Direito. O mesmo se diga em relação ao Curso Noturno, sob a regência do Prof. Alberto Moniz da Rocha Barros.

Nessa ligeira tentativa de reconstituição do ambiente intelectual das Arcadas, à época em que se verificou o concurso do prof. REALE, uma referência especial se impõe à 
notável contribuição que se deveu, para a constituição do espírito renovador, à nova processualística. São Paulo, e mais exatamente, a nossa Faculdade, foi sempre um centro conspícuo de estudos processuais. Alguns nomes, como Ribas, Joño Monteiro, João Mendes, Luís Eulalio Vidigal, Alfredo Buzaid, Moacir Amaral Santos, alcançaram mesmo, graças às suas obras, e sobretudo à influência que exerceram e exercem, renome nacional, ou mesmo internacional.

Em geral, porém, a processualística, ao contrário do que se verificou com outras disciplinas, seguiu caminho autônomo, em relação ao positivismo, ou mesmo a êle contrário. Deve, entretanto, ser aberta uma exceção notável, quanto a êsse ponto, para João Monteiro, espírito admirável, sem dúvida, mas que também sofreu o influxo das idéias dominantes à época de sua formação, nas Arcadas.

Consoante a observação do prof. Miguel Reale, "Ninguem, em São Paulo foi tão rigorosamente fiel à "concepção naturalista do Direito" como JoÃo MonTEIRo"34. Manteve-se êle, realmente, fiel, ao curso de tôda a sua vida de professor e de escritor, aos princípios positivistas, notadamente aos apregoados por Spencer. Entretanto, nem por isso ficou alheio às idéias novas, que despontavam na Europa, especialmente no campo de sua disciplina, ao final do século passado. T'alvez uma análise mais atenta da sua elaboração doutrinária, e sobretudo da sua atividade docente, pudesse demonstrar até que ponto, embora de forma indireta, teria êle contribuído para a renovação que depois se verificaria em nosso meio jurídico, com relação à ciência processual. É inegável, todavia, que na sua obra, que no seu trabalho fundamental, dedicado à Teoria do Processo Civil e Comercial, quer nos estudos de menor tomo, que deixou e que ainda hoje podem ser lidos com grande interêsse, se vislumbram os traços de sua posição filosófica fundamental.

34. Miguel Reale, Filosofia em São Paulo, p. 116. 
O inverso, como é sabido, ocorre em relação a JoÃo Mendes Junior, contemporâneo de João Monteiro e seu opositor, como representante de uma corrente filosófica divergente, e, como era inevitável, também propugnador de princípios diferentes, no âmbito da ciência processual. A posição de JoÃo Mendes cresce de significação, dentro e fora das Arcadas, dada a sua autonomia de pensamento, caracterizada pela sua fidelidade à filosofia neoescolástiça, a que se manteve fiel, de forma incontrastável, inclusive nos momentos culminantes do império do positivismo em São Paulo.

Mantém êle, sem dúvida, a linha tradicional da própria Escola, afeita ao espírito aristotélico-tomista, mesmo quando o positivismo assumiu a liderança do pensamento das Arcadas, através de Pedro Lessa.

No que se refere, especificamente, ao processo, uma notável contribuição deixou o ilustre mestre, calcando as suas conclusões em premissas filosóficas, coisa rara, especialmente entre nós. Disso nos dão idéia precisa seu Processo Criminal e o seu Programa de Ensino de Prática Forense, todos èles reeditados e ainda tão úteis, se não mesmo indispensáveis aos que desejem estudar, sèriamente, os temas processuais ${ }^{35}$.

Evidentemente, não poderia JoÃo Mendes alçar-se àquelas noções que decorreriam de uma extraordinária elaboração doutrinária, que se verificaria na Alemanha, ao final do século passado, e iria alcançar tôdas as suas conseqüências no decorrer do presente século, notadamente na Itália, através das figuras de Chiovenda e Carnelutti. Mas é fora de dúvida que as suas concepções do processo não podem deixar de impressionar, desde que se tenha em vista a época em que foram expostas. E se se abstrair dos temas gerais, para ater-se, exclusivamente, às instituições, consideradas

35. JoÃo Mendes de Almeida Junion, Direito Judiciário Brasileiro, Programa de Ensino, Apontamentos sôbre o Processo Criminal Brasileiro, todos reeditados pela Editora Freitas Bastos. 
em suas peculiaridades, não se poderá deixar de reconhecer os méritos excepcionais das análises que, a respeito delas, oferece.

Chamam, especialmente, a atenção, as considerações que tece a respeito das instituições processuais penais, cuja vitalidade, pràticamente, se mantém intacta. Diretrizes que, ainda hoje, se adotam na vida forense, a respeito de situacoões processuais penais, decorrem, diretamente, do seu tratado de processo penal, que assim continua a ser uma obra da maior atualidade.

Seria, entretanto, necessário aguardar a atuação de uma nova geração de processualistas, tôda ela formada sob as Arcadas, para que a ciência processual alcançasse a plenitude do seu desenvolvimento, ao impulso da inspiração de novas idéias e novos princípios. Luís Eulalio dE Bueno Vidigal, Alfredo Buzaid, Moacir Amaral Santos, lopes da Costa, José Frederico Marques, entre outros, recolheriam essa inspiração fundamental, que nos vinha da Alemanha e da Itália, para imprimir rumos definitivamente científicos ao processo. Um fato, aparentemente sem significação, contribuíu decisivamente para que isso ocorresse. Foi a presença de Enrico Tullio Liebman entre nós, especialmente em São Paulo. O que isso representou, para o desenvolvimento dos estudos de direito processual no Brasil, di-lo, de maneira insuperável, Alfredo Buzaid "A presença de Liebman entre nos significa a alvorada do direito processual civil como sistema cientifico. A sua passagem pelo Rio de Janeiro, embora curta, já prepara uma escola, dirigida por Eliezer Rosa. Este ilustre processualista, ungido de fé, mantem há vinte anos um curso, formando sucessivas turmas de iniciados no culto da ciência. A prolongada permanência de Liebman em São Paulo foi a dádiva maior. Tanto que iniciou o magistério da Faculdade de Direito, viu-se logo cercado por um grupo de estudiosos. Estes primeiros discípulos, ávidos de saber, encontram em Liebman um sábio, pródigo de bondade e de dedicação. Começa aí o fadário do mestre. O ofício de 
ensinar não se cinge à atividade de rotina na universidade; prossegue, com vibrante entusiasmo, na residência, onde o mestre recebe os discípulos todos os sábados. A casa da Alameda Rocha de Azevedo se transforma no berço do movimento de renovação cientifica do direito processual civil. Vários dos discipulos, conquistando a cátedra, se esforçam por corresponder às esperanças do mestre. Fundam o Instituto Brasileiro de Direito Processual Civil, hoje orgão anexo da Universidade de São Paulo; publicam a Revista de Direito Processual, a quinta editada no mundo; realizam dois congressos, um internacional e outro nacional. Bastaria este legado para fazer a gloria de Liebman. Mas o mestre não para aí. No plano puramente intelectual, escreveu, alem das notas às Instituições de Chiovenda, numerosos artigos e conferencias, que vêm a lume nos Estudos sobre o Processo Civil Brasileiro (Saraiva e Cia., São Paulo, 1947) e, por derradeiro, o Processo de Execução (Saraiva e Cia., São Paulo, 1946 e 1963), como que para cingir de loiros a despedida do Brasil. O pensamento de Chiovenda e de Liebman está vivo. Fulge nas lições dos professores, nos acordãos dos Tribunais, nos debates doutrinários dos tratados, manuais, artigos e dissertações de concurso" ${ }^{36}$.

Os mestres de processo civil, hoje, em São Paulo, e em algumas das principais faculdades do país, foram discipulos de Liebman ou se filiam à sua orientação. Na Faculdade de Direito de São Paulo, o predomínio atual das novas idéias processuais é absoluto, através de Luis Eulalio Vidigal, Buzaid, Moacir Amaral Santos, Moacir lobo da Costa, Celso Neves, Tomás Pará Filho, Luís Ambra, José Inacio Mesquita.

$\mathrm{E}$ já se incorporaram, fundamentalmente, ao sistema positivo, através do Código de Processo Civil, em vigor, sendo ainda mais larga a sua atuação no anteprojeto de Código de Processo Civil, elaborado pelo prof. Alfredo BuzaID.

36. ALFREDO BuZAID, introdução à $2 \cdot^{\mathrm{a}}$ edição da tradução brasileira, de J. Guimarães Menegale, das Instituições de Chiovenda. Edição Saraiva, São Paulo, 1965. 
Deve ponderar-se, entretanto, que a situação atual não corresponde à que formava, em 1940, quando Reale fêz o seu concurso, à mentalidade dominante nas Arcadas. Naquela ocasião, conforme já se salientou, refulgiam ainda, em últimos lampejos, as inspirações positivistas, ou mais exatamente, naturalistas, e as idéias neoescolásticas, propugnadas por autorizados intérpretes. De certa forma, como se depreende da reconstituição que acabamos de fazer, a Faculdade se manteve sempre fiel às suas diretrizes básicas, numa dicotomia constante entre tendências naturalistas e aristotélico-tomistas.

Fácil é imaginar o que representou, portanto, para o ambiente então existente, a tese do candidato, os Fundamentos do Direito, que se desgarrava das duas orientações básicas, e vinha enveredar por um caminho novo, num convite aberto aos jovens e aos mestres para que o experimentassem. Tinha, sem dúvida, um tom marcadamente polêmico - e isso ressalta de cada uma de suas páginas -com relação às posições tradicionais, mas tinha sobretudo uma mensagem de renovação, que iria constituir, com o desenvolvimento posterior da teoria esboçada, uma contribuição inestimável para o pensamento jurídico brasileiro e mesmo extracontinental. 